\title{
"Carving out an identity for itself": The Work of Telos over Forty Years
}

\author{
Elisabeth Chaves
}

When a group of graduate students at the State University of New York-Buffalo began Telos in 1968, they created a publication that would still be in existence more than forty years later. I can imagine that in May 1968 as the first issue of Telos circulated, it passed from hands to hands in university building hallways, its corners becoming bent with its increased circulation. Perhaps the table of contents advertised on its front cover too closely resembled the dry publications that proclaimed themselves to be scholarly works. It hid its status as a radical publication, foregoing any cover art that shouted its provenance. Its readers that would later become its editors first encountered it among the stacks in the darkened corners of college libraries. Maybe with some of the excitement of Howard Carter entering King Tut's tomb, they opened the cover of the unassuming journal to find exotic ideas and foreign names. More likely, since I cannot imagine that college students have changed all that much, they took one look at the cover and an article title like "Theory, Empiricism and Class Struggle: On the Problem of Constitution in Karl Korsch" and moved on to the next item on the shelf. But for the brave or crazy few, the journal would quietly enter into history and persist there mostly unnoticed on the margins. That this was a conscious strategy and not just a result of its nature will be discussed more below.

Today, if they had the time to spare from their teaching and research assistantships, conference papers, papers for publications, teaching loads, and the other bases to be covered on the way to landing an academic position, graduate students might start up a journal, especially if it might also increase their attractiveness to a future employer. Likely empty of any political rhetoric aimed at any specific target and not free of footnotes and hallowed names, the student journal of today would probably be published on-line, suiting academic budget constraints. Also, as an electronic journal, the students could envision the world-wide audience that would stumble across their site, attracted by its title, and then captured by the effects of its well-designed style sheet.

Changes in the media ecology create disruptions sometimes larger than the seemingly simple change in materiality might suggest. A shift in legitimacy can occur through the introduction of a new technology. Are newer electronic journals as legitimate as print journals? These shifts can also affect the structure of the intellectual field. This article will utilize the field theory of the sociologist Bourdieu.

\footnotetext{
The intellectual field, which cannot be reduced to a simple aggregate of isolated agents or to the sum of elements merely juxtaposed, is, like a magnetic field, made up of a system of power lines. In other words, the constituting agents or systems of agents may be described as so many forces which by their existence, opposition or combination, determine its specific structure at a given moment in time. In return, each of these is defined by its particular position within this field from which it derives positional properties which cannot be assimilated to intrinsic properties and more specifically, a specific type of participation in the cultural field taken as a system of relations between themes and problems, and thus a determined type of cultural unconscious, while at the same time it intrinsically possesses what could be called a functional weight, because its own 'mass,' that is, its power (or better, its authority) in the field cannot be defined independently of its own position within it (Bourdieu, 1969, p. 89).
}

I am interested in three things: first, what is Telos's position within the intellectual field; second, how has this position changed over time; and third, how have changes in the materiality of communication altered its position. Answering any of these questions fully requires more space than is available here. So, I treat what follows as beginning 
explorations into these areas, especially the third.

While the arrival of electronic media, including the television, and now "new" media, such as the Internet, have altered positions within the intellectual field, I do not think it is possible to create a before and after argument. These changes are sometimes gradual and sometimes abrupt, and they interact with other social, political, cultural and economic changes to produce varied effects. Further, communication technologies not only act upon subjects and objects but also are themselves acted upon. So, they cannot be the single focus of attention. As I mentioned before, Telos' perhaps willing push to be a journal on the margin also obviously affects their position. Still, as Debray argues, the role of new information technologies cannot be underestimated:

This sudden rise to power of [the information] apparatus that was formerly subordinate or peripheral has had the side effect of shattering the coordinates of the 'intellectual field,' taken here to mean 'the system of social relations within which creation takes place as an act of communication.' [citing Bourdieu, "The Intellectual Field and the Creative Project"]. The order of its coordinates has changed, but inversely. Spatially, there has been a broadening of the base; temporally, a narrowing. Increase in the potential audience; decrease in creative intensity: is it possible that the modern humanities have lost comprehension and gained extension, like the concept in classical logic?" (1981).

However, understanding Telos's position on the margin of the intellectual field does not entirely rest on tracking its shifts through changes in the rise of the information apparatus. That is part of the story, but not the whole story. We will have to hold two things in mind at once, that the position(s) in the intellectual field can change, and that changes in technology/media ecology can affect those shifts but are not the only cause of those shifts.

Furthermore, while it is easy to analyze Telos as a marginal journal, since the journal so named itself, and while there seems to be nothing more absorbing for scholars and intellectuals[1] than describing the intellectual field and defining where someone, something, or they themselves fit within it, tracing the history of Telos as a journey through the intellectual field cannot be the whole story either. At worst, this analysis will portray the intellectual field as static, while presenting a structuralist theory that makes defining Telos as dependent on the definition of the New Left Review or The National Review as on anything having to do with Telos itself. At best, I might write a very neat and tidy argument that ties Telos' every move to shifts in the intellectual field and thus create some real insight into the journal's history-insight that would seem not to depend on the actual political content or, maybe a coarse word, motivation of the journal. Rather than depicting a journal and its editors and authors trying to influence political thought or practice, I could write the story of a journal and its associates trying to carve out a consecrated position for themselves within the intellectual field. Neither analysis seems particularly worthy nor whole but maybe somehow taken together a thicker analysis might be derived? This article, in the space available, will contribute to the latter, the analysis of Telos' position within the intellectual field. Hopefully, this issue, taken as a whole, will improve my limited contribution.

\section{Mapping the Field}

As I said before, scholars and intellectuals regularly map the intellectual field, assigning positions to the objects of their study, in an attempt to what? - create markers so that they can best navigate the intellectual landscape that is their environs; define what are legitimate positions within the field and which are not; or, maybe to gain some understanding of the social world, or even to facilitate some action within it. Additionally, while not always surveying the field, efforts like this issue that seek to answer questions of the impact and legacy of an intellectual object, also can be explained in terms of this field logic. They are attempts often to shore up or tear down certain positions within the field or perhaps make room for new positions while honoring the old position's passing. I agreed to contribute an article to this effort, so I too am playing a role in the construction of the field. Therefore, my own position should probably be explained.

I am a doctoral student working on a dissertation at Virginia Tech in Blacksburg, Virginia. I was born almost a decade after Telos began publication. My advisor, Tim Luke, has been and continues to be involved with the journal. I am studying Telos as part of my dissertation. This article will aid my professionalization as an entry on my curriculum vitae, but it will also help me in my studies, which I hope will make a valuable contribution to some body of knowledge. I have also, along with a group of other graduate students, begun a student-run electronic journal here at Virginia Tech, not unlike the one described above. Therefore, I apologize to any graduate students undertaking a similar endeavor with perhaps loftier or different goals. I do not know if I can say whether I have attained a 
recognized position within the intellectual field. An interesting study would simply be to define what is required to enter the field today. So, I approach this analysis from somewhat of an outsider position, probably more outside Telos than most of the other contributors to this issue, and outside, or at least, on the borders of the intellectual field, and yet my survey of the field might be the creation of my entryway to it, or perhaps some sort of reconnaissance for a future mission.

In a similarly reflexive vein, Telos has provided recaps of its history over the years, publishing self-examinations, at fifty issues, at the age of twenty, at one hundred issues, and at the death of its founding editor, Paul Piccone.[2] So, while I try to map Telos's position within the field, I am also using its past navigations to aid my own. Obviously, this approach can be problematic, as I am relying upon the object's own analysis for my analysis. (And I am somewhat confusing myself here too in this M.C. Escher infinity loop). Further, as I reviewed these past reflexive excursions in the journal, I was struck by how well the language of their own analysis matched my expectations (if that is the word) after having studied Bourdieu, upon whom the analysis of this article is largely based. I then wondered if perhaps the editors and contributors to Telos had somehow internalized Bourdieu for themselves and reproduced his "findings" in the telling of their own history. [3] If this is the case, then this internalization would only seem to confirm Bourdieu's argument that the field of production, whether cultural or intellectual, is a collective effort, and the public meaning of a work is collectively defined.

The relationship with any work, even one's own, is always a relationship with a work which has been judged, whose ultimate truth and value can never be anything but the sum of potential judgments of the work which the sum of the members of the intellectual world would formulate by reference in all cases to the social representation of the work as the integration of individual judgments of it (Bourdieu 1969).

Some may argue that Bourdieu's field analysis is not useful or is flawed. I will not argue against the latter. And as I said above, tracing Telos's position within the intellectual field may not get us close enough to the Truth of Telos. However, mapping has become a catchword in academic and intellectual discourse, especially on the Left. There is a lot of talk of the need to map. Positions, locations, and spaces appear to have become fundamental to understanding ourselves as subjects and objects, especially in our hypercapitalist world. Our epistemologies seem to rely so much on being able to understand the terrain of knowledge, its geography. Some argue this is a question of space, others say place, where others put us in spheres, scapes, flows, fields, networks, ecologies, and hegemonies.

I am still grappling with this process of "mapping," or the use of the spatial as an analytic tool, as I think many others may also be doing. Mapping can act as a stabilizer in an unproductive, dominant way, putting subjects and objects in "their" place. But arguably, a map can also serve as a useful guide giving a sense of direction to a political or social movement that may at present be lost. For Bourdieu, mapping is a means of navigating the field of production, recognizing the terrain, important landmarks, etc., that allow an occupant of the field "to be able to navigate in a hierarchically structured space in which movement is always fraught with the danger of losing class" (1993).

Space has become destabilized in that so many diverse readings of it are possible, or perhaps these multiple means of sense-making have led to the destabilization of space. As Lefebvre and Jameson suggest, some sort of recomposition or stabilization that makes sense of space may be necessary to a political project, especially for the Left that seems to have lost many of its markers. To quote Lefebvre

The reconstruction of a spatial 'code' - that is, of a language common to practice and theory, as also to inhabitants, architects and scientists - may be considered from the practical point of view to be an immediate task (Lefebvre 1991).

And Jameson also states that

[T] he conception of space that has been developed here [in his outline of postmodernism] suggests that a model of political culture appropriate to our own situation will necessarily have to raise spatial issues as its fundamental organizing concern (Jameson 1984)

This re-composition may recreate critical distance. But are all these mapping impulses really efforts to reclaim some political agency for a collective movement or group? Or, following Bourdieu, do we continue to draw maps of our field in order to secure our (individual) position within it?

What I am struggling with is the question of whether this is an entirely cynical outlook that appears only to give intellectuals a self-serving raison d'etre. Bourdieu presents his arguments for the field and its construction, but he never seems to judge it. I guess this is left to others, including us. And, to repeat myself once more, even if we 
follow Bourdieu here, it does not mean that we have captured the impact and legacy of Telos in all its complexity and can check it off our to-do list. However, incomplete or not, I believe the use of field analysis does add something to our understanding, and as more and more attempts to map the field are made, I cannot help but think that there is a strong argument to be made for this analysis.

For example, a 2007 article in the New Left Review by Goran Therborn demonstrates the ongoing desire to map. In the article, Therborn attempts to create a map of the current positions within the Left (Therborn 2007). They include post-socialists, non-Marxist leftists, Marxologists, post-Marxists, neo-Marxists, and resilient Marxists. He also explores different thematics on the Left, from an interest in theology, to sexuality, to networks. He emphasizes the need for mapping but notes that with the loss of Marxism as a compass, "it should be expected that this [creation of new bearings] will take some time" (Therborn 2007). Again, this article can be read as an attempt to trace various theoretical horizons in order to find the paths of best resistance to capitalism, or it can be read as a means of firmly situating various thinkers in the field, reifying their positions, and maybe demonstrating their value by defining their difference while also somehow limiting their value to the space they occupy.

\section{| Jockeying for Position}

In steeplechase racing, the "field" refers to the horses and their riders. The jockeys must carefully position their horses as they take each fence so as to come out in a dominant position on the other side. This jockeying for position occurs at each fence, before a winner can be declared at the race's finish line. In other words, the positions are continuously shifting; they never become set or secure until the end of the race. Telos is still a publishing journal, so it would be premature to call its final position, if it can ever be determined. However, it may be useful to review its past and present negotiations through the intellectual field.

Telos, began in May 1968 as a journal of radical philosophy. Paul Piccone, the founding editor of the journal, stated that "[i]t is no accident that one of the early subtitles of Telos was 'a journal definitely outside the mainstream of American philosophical thought" (2008a). From its inception, Telos sought to distinguish itself from other players within the intellectual field. First and foremost, the journal chose to separate itself from academia as best it could, despite its birthplace being the philosophy department at SUNY-Buffalo - an illegitimate birth, as the journal was never formally institutionalized as belonging to SUNY-Buffalo or any other university. For the journal's founders, academia was not a productive setting for the type of philosophical and political thought that interested them.

Whatever still passes for radical thought today has long ceased to be an alternative promising to revitalize or threaten anything: it lingers as a barely tolerated subspecialization for marginal intellectuals seeking to bypass traditional exclusionary mechanisms of an academic establishment infested through and through, like all similar institutions, with clientelism, nepotism, and assorted run-of-the-mill biases. Today's academic radicalism prefigures, at best, only a modest academic career and a comfortable intellectual retirement (Piccone 2008a).[4]

Ironically, the Western Marxism and Critical Theory that the journal would introduce to its largely North American audience would also become canonized and consecrated by the University. The journal's strategy to place itself outside the scholarly field and into the intellectual field would cause many of its editors and contributors to live double-lives, writing for a journal that garnered little favor in academic circles, especially when it came to tenure review, but holding jobs within academia that could professionalize even the most resistant.

The journal's desire to position itself outside the bounds of academia precluded, as mentioned above, the journal from ever finding a university home, or much regard within the university. [5] This strategy of non-institutionalization, however, exceeded any anti-academic intention to include a fear of institutionalization of any sort. Piccone asserted that this non-institutionalization saved the journal from conformity (2008a). Again, the journal "chose" a dominated pole rather than the dominant pole of the intellectual field. How much of this choice was a conscious strategy, or maybe more accurately, how much of this choice was a choice, implying that there were other options, could be debated. However, choice or not, this non-institutionalization, in academia or elsewhere, helped keep the journal distinct from other positions within the field, and it reveals a kinship to artists within the field of cultural production that choose to practice art for art's sake, disdaining the economic and political power found at the dominant pole because it would interfere with the "purity" of their art (Bourdieu 1993). I will return to this idea below.

The journal also somewhat distanced itself from the political movement that it appeared closest to, the New 
Left. Piccone insisted that the publication of the journal's first issue in May 1968 was strictly coincidence. Still, a group of graduate students did form the journal during this time - a group largely comprised of working-class and lower-middle class students in philosophy at SUNY-Buffalo. Further, while not identifying themselves with the New Left movement, the journal's editors and contributors saw their project as one in common with the New Left, although not the same.

The objective [of the Telos project] was always to vindicate the ineradicability of subjectivity, the teleology of the Western project, and the possibility of regrounding such a project by means of a phenomenological and dialectical reconstitution of Marxism in conjunction with the New Left (Piccone 2008b).

With the collapse of the New Left, Piccone labeled the journal a "political orphan," and asserted that the journal needed "to rethink its identity and to revise its project" (2008a). These comments were made retrospectively in 1988. Six years later, again in one of the journal's reflexive analyses of its past, Piccone added that

[t]he phenomenological project of an epistemological foundation for an otherwise arbitrary dialectic (understood as the Weltanschauung of a movement presenting itself as a radical alternative to the given) did not collapse. It only became superfluous with the disintegration of the political structure that it was ultimately meant to support (2008b).

This latter statement seems to suggest that the journal's identity was not necessarily dependent on the existence of the New Left, but that the journal's project became irrelevant without it. Other editors and contributors may disagree with Piccone's assessment. I argue though that this difference lends support to placing Telos within the intellectual field, rather than the political, and again points to the journal's kinship to those artists practicing art for art's sake. Not meant disparagingly, Telos practiced theory for theory's sake, and this placed the journal farther away from other publications more directly influenced by or positioned within the economic and political fields.

This distancing from other publications was also a product of the journal's style and content. The former, what one of Telos's past contributors called the "journal's notoriously hermetic style" distinguished the publication from other New Left publications that were more accessible and could be more easily culled for slogans and statements for the movement (Breines 1988). Again, the parallel can be drawn to the artists in the restricted field of production creating art that could be read neither by the bourgeoisie nor the masses.

A look to the past provided the foundation and beginnings of Telos and also influenced its style. As Piccone stated, "[w]e began to search for forgotten and repressed texts that we had occasionally seen mentioned in passing or referred to in stray footnotes" (2008a). Remembering may help orient a journal, allowing it to see how it differs from other projects. As Adorno remarked,

'All reification is forgetting,' and criticism really means the same as remembrance - that is, mobilizing in phenomena that by which they have become, and thereby recognizing the possibility that they might have become, and could therefore be, something different (Adorno 2000).

Telos's dependence on past texts shaped its identity. Whereas most academic journals in political science or sociology consider their intellectual heritage to be the past five or ten years, Telos looked to the past fifty or hundred years (Agger 2000).[6] As Piccone stated, "[o]ur critique had to speak a language other than that of our opponents, and this necessitated the resurrection of otherwise forgotten philosophical traditions (2008a) (emphasis added).

Further, many of the figures the journal published and wrote about were individuals who had also lived on the margins, having little political impact and small audiences. Paul Breines, who resigned from Telos in the mid-80s due to disputes, recalled a question posed by Robin Blackburn of the New Left Review at an early Telos conference in Waterloo, Ontario, where Blackburn essentially asked why Telos was so interested in publishing these marginal figures.

I do not recall how any of us responded at the time, but I would say now that the very lack of political success, the distance from actual power typical of these figures, their isolation, are in crucial respects the very things that drew us to them, their marginality serving as the ideal outpost for the activity of continual criticism. That we ourselves, for reasons both circumstantial and subjective, were in fact far less marginal that were our models and heroes is also part of the picture - the picture of Telos' formative desires (Breines 1988).

Bourdieu traces a similar return to the past by avant-garde artists, calling this "return to the sources" the "strategy par excellence," as it forms "the basis of all heretical subversion and all aesthetic revolutions, because it enables the insurgents to turn against the establishment the arms which they use to justify their domination" (1993). 
The journal also included their contemporaries, specifically in the form of critiques of other journals. Begun in 1974, Telos published a section of Short Journal Reviews that "grazed rather widely" and were often quite critical. The journal's Toronto group was largely responsible for writing these critiques. Members of the group remember being directed to make the reviews "damning” (Genosko, Gandesha, and Marcellus 2002). Once again, Telos sought to distinguish itself from the other occupants in the field, especially those similarly situated. "[T]he self-image of Telos rested from the very beginning of the publication on special, most often not very flattering attention being paid to other new journals, especially those staffed by other graduate students" (Genosko, Gandesha, and Marcellus 2002).

Fast-forward to today and Telos itself is the subject of a journal critique within the Times Literary Supplement. While the journal desired to be chosen for a TLS critique, presumably so as to gain a wider audience, I wonder if this move does not run counter to the journal's long-professed intention to be a marginal journal. Now, in the TLS anyway, it is one journal among other "Learned Journals," the title of the section in where the critiques appear, which also makes it appear old and stodgy. Further, the TLS placed the journal under the subsection of "Social Studies," in a sense re-disciplinarizing it and academifying it. Lastly, the critique explicitly questioned the journal's carefully cultivated (former?) position within the intellectual field, stating that "Telos still vaunts its anti-orthodoxy, but might not many of the ruling powers in the world today, if they shared the vocabulary, define their own double-thinking views similarly?" (Leslie 2008). Presumably, the "double-thinking views" is the author's reference to the journal's use of controversial figures like Carl Schmitt in what was, or what was read as, a journal on the Left. I will return to this issue below.

Another way the journal was able to distinguish itself was through the creation of the concept of artificial negativity as an aid to understanding the continued vitality of capitalism and its co-option of intellectuals as members of the New Class, an expression borrowed from the journal's literal next-door neighbor, Alvin Gouldner. Due to my limited space here, I will refer the reader to an article titled "Artificial Negativity as a Bureaucratic Tool" originally published in issue eighty-six of the journal for a full discussion of the term. This concept became a hallmark of the journal and can be viewed as a contribution made by the journal to political theory, although it is not without its critics.[7] Telos's own reflections on its history and also reflections found outside the journal have emphasized the journal's introduction of the artificial negativity concept. This memorialization of the contribution, in a way, serves to reify the concept. Further, it is indicative of intellectuals' need to label themselves or other intellectuals with identifiable markers that position them within the intellectual field. "Oh, you're talking about the Telos crowd, the ones that came up with artificial negativity." Immediately, this places the journal and its associates in a certain place within the field, perhaps on the Left, on the dominated pole, near Theory and Society, sort of, and opposed to neoliberal ideas. I am not yet making the argument that the journal sought to distinguish itself with the concept of artificial negativity or wanted the journal to become self-identified with it. However, this thematization, as Jameson has named it, while carving out a certain identity for an intellectual position can become totalizing (Jameson 2009). Adorno warned of this tendency when he said,

\begin{abstract}
As very often happens in the case of major intellectual phenomena, when the unity and grandeur of their original conception disintegrates, individual fragments are torn out by the epigones, who each seek a chunk for themselves, if you will forgive me in this inelegant image, and regard it as the philosopher's stone by which absolutely everything can be explained. In contrast to this, the truly important conceptions are almost always distinguished by the fact that they do not include any such magic words, that they do not have any specific category by which everything can be explained once and for all. Rather, they form contexts or constellations of categories as a means of explanation, instead of calling on one of them to be a maidof-all-work. But-and this is a socio-psychological observation-just when a theory has a keyword, such as Jung's 'collective unconscious' or Durkheim's 'collective consciousness' or whatever it may be, such 'maxims', as Hegel already termed this phenomenon, take on a peculiar suggestive power. And one can only encourage scholars who want to make their mark in the world and have a big success in the market to think up such a 'maxim,' some single category that can be attached to everything, so that everything under the sun is given a label (2000).
\end{abstract}

With the decline of the New Left, the pessimism engendered by the theory of artificial negativity, and the rise of the video age, the journal began to look to rather controversial sources for new inspiration that caused the journal to gain a reputation as "conservative" and "right-wing". (As still, relatively-speaking, a youth, I might add that the ageing, coupled with the institutionalization in university-life[8], of the journal's earlier founders, editors, and contributors may have also played a role. Churchill's famous phrase leaps to mind.) For Piccone, this conservative involution could itself be considered a radical move. 
At a time when the collective amnesia of a generation raised on MTV tends to collapse the past in the immediacy of the image, traditional conservatism may take on a new radical role. As Gross has put it, by refunctioning alternative models, tradition provides the means to establish a critical distance from an otherwise ubiquitous present whose very being constitutes its own legitimation (2008b).

By the late 1970s, the journal had already given Marx his proper burial, and by the early 1980s, the journal was becoming more and more outspoken in its anti-communism, especially of Soviet-type systems. As Breines recalled,

That this amounted to an articulation within the journal of the broader neo-conservative tendency underway outside seemed to me, as it did to some other editors as well as some discontented readers, quite obvious. But that only enhanced... its dynamism. For leaving aside the substance of the issues, Telos' new anti-communism drew energy from the very act of violating a number of not only Old Left but also New Left taboos, and transgression (in political if not in social or cultural terms) is in our milieu a highly valued activity (1988) (emphasis added).

Unlike Piccone's comment that suggested the journal's "conservative turn" to be a source of energy and/or creativity, Breines points to the value of transgression in the intellectual field as, I would argue, an end in itself for purposes of position-taking. Transgression for transgression's sake, perhaps functionally alike but more routinized than art for art's sake, becomes a position within the field in and of itself. In his discussion of avant-garde art, Bourdieu examines the "ritual sacrilege" of certain artists attempting to destroy any link between the artist and the economic field. However, these are failed attempts, since

Art cannot reveal the truth about art without snatching it away again by turning the revelation into an artistic event. And it is significant, a contrario, that all attempts to call into question the field of artistic production, the logic of its functioning and the functions it performs, through the highly sublimated and ambiguous means of discourse or artistic 'acts'... are no less necessarily bound to be condemned even by the most heterodox guardians of artistic orthodoxy, because in refusing to play the game, to challenge in accordance with the rules, i.e., artistically, their authors call into question not a way of playing the game, but the game itself and the belief which supports it. This is the one unforgivable transgression (Bourdieu 1993).

While Telos has taken pride in its transgressions over the years and used its functionality to carve out an identity, I think it completely oversimplifies the journal to say that its mode of operation is just transgression for transgression's sake, and not just because to think this way would imply that Telos disregards the intellectual field in toto. However, the journal's style and its affinity for the margin, and letting everyone else know that it prefers the margin, may give the impression that heterodox is not just a manner of critique but a way of being.

To the charge that the journal has become "right-wing," one of its not-uncritical contributors replied in 1994, "[n] ow most of those who say this are just not reading the journal closely (or are reluctant to question old beliefs). But our style invites misinterpretations" (Ost 1994). Again, the journal's style, a strategy for positioning itself in a certain place within the intellectual field, can substitute appearance for substance. Further, the journal's past strategies, or position-takings, accumulate and harden into its most current identity. More clearly, the public meaning of Telos contains within it all the past positions; no reading of the journal now can be divorced from what the journal was, becoming a source of confusion for some. Moreover, those very readings also transform the journal, as its editors and contributors, whether consciously or not, incorporate them into their work.

The incessant explication and redefinition of the foundations of his work provoked by criticism or the work of others determines a decisive transformation of the relation between the producer and his work, which reacts, in turn, on the work itself. Few works do not bear within them the imprint of the system of positions in relation to which their originality is defined; few works do not contain indications of the manner in which the author conceived the novelty of his undertaking or of what, in his own eyes, distinguished it from his contemporaries and precursors (Bourdieu 1993).

Therefore, it makes almost no sense to try to divine some break where Telos abandoned its Leftist roots and joined the conservative camp. However, criticisms, like the following, are fair, because they question not an identity or fixed position but the product instead.

The problem is that Telos has moved out of its marginality, but seems unwilling to face the responsibilities that come with this. Telos has in fact become a kind of policy journal. But it has done so only half-way. Telos is now routinely crammed with recommendations for the dismantling of all kinds of state programs that allegedly only help the interests of the New Class elite. At the same time, there is an almost complete absence of any systematic analysis of the real implications of such policy recommendations. The problem, in other words, is not that the journal has changed, but that it has not changed enough (Ost 1994). 
Even though Piccone once wrote in 1988 that after the Habermasians left the journal's editorial board the time was ripe for the journal to settle its theoretical identity, arguably, no such settling has occurred (Piccone 2008a). My argument here is that such a consensus is not possible, since it depends upon fixing the journal at a particular time and place. Further, with changes in the media ecology and the often temporary nature of new media, this "fixing" becomes even more difficult. And such a consensus would also depend upon the perceptions of the audience, the journal's readers, and their perception also shifts with changes in society. To quote from Piccone at length,

\begin{abstract}
If a journal manages to survive for 100 issues, it is reasonable to assume that the editorial board has managed to reach some sort of internal consensus and can finally rest on its laurels. Such is not the case with Telos. Far from constituting a selfcongratulatory occasion, the editor's critical reflections on the history of the journal amount, at best, to a collective roast or, at worst, a theoretical free-for-all. The closest they come to a consensus is a general sense that there has been a conservative involution, that the analyses being published are becoming increasingly indistinguishable from those articulated elsewhere, and that there is a tendency to follow popular political fads. Whatever this may mean, it certainly does not betray internal complacency. After all of these years, nothing seems to be settled [emphasis added], and the editorial board remains a hopelessly heterogeneous group still trying to come to some agreement concerning many crucial and not-so-crucial issues, such as precisely what constitutes this conservative involution, who has fallen victim to it, what the journal originally sought to accomplish, what it in fact has accomplished, and what it should be doing now and in the future. While predicaments of this kind usually denote widespread confusion, they can also be the source of creativity. This is why this theoretical bellum omnium contra omnes may be interpreted as evidence of lingering internal vitality, an unwillingness to take anything for granted, and a suspicion of all positions even faintly resembling conformism and passivity. The point of departure in confronting such a predicament must be a critical reevaluation of what Telos has been for more than a quarter of a century, and where it fits both within the short parabolic trajectory of the New Left and, more generally, within contemporary intellectual history (2008b).
\end{abstract}

To further complicate things and to return to the opening of this paper, I must reinsert the question of how changes to the intellectual field made by new forms of communication affect Telos's identity and position in the field. How does the changed materiality of communication alter perceptions of legitimacy, which influence who is listened to and who is disregarded. How does it alter the journal's project? How does it shape or reshape the journal's present, future, and even past identity?

To begin, the journal has made the last ten years of its articles available in electronic format. For a reader new to Telos who may only have access to the electronic articles or may choose only to read those, that reader may arrive at a different understanding of the journal than someone who reads farther back into the journal's history or experiences the journal in its print form where, for example, ads for other journals help provide context for itself. Also, you can now search the journal on-line through TELOSthreads and look up articles by author and subject area, to name some of the filters. A reader can take from Telos whatever piece he/she likes. Readers no longer have to struggle to accommodate or make sense of all the various positions represented. Does this mean that the journal's identity or position within the intellectual field is now more in the control of the reader? Is complexity being sacrificed to visibility?

Additionally, how do the journal's recent forays into social networking sites like Facebook and Twitter affect its position? Does a marginal journal tweet? How do such efforts shape the journal's audience? The TELOSscope blog now found on the journal's website also creates more interaction between journal and audience. Readers can become writers as they post comments (reactions) to the blog posts written by Telos contributors. The very existence of a website for the journal may allow it to reach more readers than it otherwise would, but how do all these new media extensions of the journal affect the journal's project? Someone's energies, whether owner's, editors' and/or contributors', are going into the creation and maintenance of these electronic manifestations of the journal rather than into the construction of the print journal itself. Does the understanding of the journal as an embodiment of both print and electronic forms also affect the nature of the journal's project? In other words, do they effect the telos of Telos. As I stated above, I can only begin to ask these questions as most of these new media changes to the journal are in embryo. However, what I can say with more certainty is that Telos is an ongoing pursuit, and I doubt that it has reached its final position within the intellectual field. 


\section{Endnotes}

1. It seems that Bourdieu presents these as occupants of two separate fields. At least, he refers to them separately or independently of one another. I think this may be an arguable point. But for purposes of this paper, I will consider scholars as those who produce works for or within the university while intellectuals produce works for or outside the university. This does not preclude someone from being a scholar and an intellectual.

2. See, for example, Issue 50, Winter 1981-1982; Issue 75, Spring 1988; Issue 101, Fall 1994; and, Issue 131, Summer 2005.

3. The journal published an essay by Bourdieu in their 81st issue in the Fall of 1989 titled, "The Corporation of the Universal: The Role of Intellectuals in the Modern World."

4. Lest this be considered a harsh indictment of academia, Piccone also had this to say, "today Telos thrives outside a mainstream which mostly does not understand it, does not appreciate it, and, because of the widespread prosperity generated by new technological innovations, need not take it seriously. Safely mothballed in universities, most intellectuals write articles no one reads, debate issues no one cares about, and continue miseducating students in dire need of official certification (who are actually acculturated not by the universities, but by the culture industry). Seemingly obsessed with seeking to resolve self-perpetuating pseudo-problems of race, class, and gender, most intellectuals, posturing as the self-righteous opposition, while, in fact, legitimating the totally administered society, are even worse off than Gregor Samsa, who at least was troubled by his strange metamorphosis. Presumably, it beats the hell out of holding a regular 9-to-5 job. Within such a context, Telos remains the project of a few intellectuals and of a limited readership still interested in Truth, and optimistic that, despite the general cultural decline, there are still a lot of possibilities for a society so mesmerized by its material success to be able to ignore or even to formulate its spiritual impoverishment" Piccone, Paul. 1999. "elements Interview." Telos 117:133-166.

5. "Although it proclaimed itself to be a philosophical publication, its actual disciplinary attachment was hardly clear, which to most academics signified incoherence rather than promise, not to mention the fact that, instead of currying favor or buttering careerist bread, the opening editorial statements in the early issues calmly denounced as totally bankrupt and conformist virtually every known school of American philosophy. The editorial group, moreover, was composed of graduate students, meaning that manuscripts were not refereed by known scholars. Finally, in this connection, Telos was emphatically and explicitly linked to Marxism and to the Left at a time when intellectual work from this camp had not yet achieved credibility in university environs" Breines, Paul. 1988. "Recalling Telos.” Ibid.75:36-47.
6. However, this reach farther back into the past could have its problems. "[T]he very impulse to construct a historical tradition [Western Marxism from the 1920s-1950s] for ourselves tended to blind us to much of the originality of our own historical situation and of the social movement to which we were definitely, if often uneasily, linked" Ibid.

7. For example, "An extreme form of this 'State' omnipotence is the 'artificial negativity' thesis put forward by Telos editors Piccone and Luke. Outdoing Marcuse's 'one-dimensionality' tendencies of the late 1950s and early 1960s, Piccone and Luke argue that 'the New Left along with the various counterculture movements of feminism, black consciousness, and student activism were part of the constitution process of artificial negativity.' So too were the victories in Vietnam, Angola, Mozambique, plus nearly every anticapitalist protest and struggle during the 1960 s and 1970s. Without all these internal and external forms of opposition American capitalism would become irrational and develop internal problems with which it could not cope. Thus what is needed are 'social counterweights to the bureaucracy. I order to provide these, it is necessary to reconstitute internal critique and opposition-so much so that where these critiques and oppositions do not develop spontaneously, they tend to be bureaucratically planned.' It is interesting to note that Piccone and Luke's extreme pessimism goes together with an overinflated admiration for the foresight of 'State' and 'Capital.' In this scenario the 'rationality' of capitalism can never really lose; for if all the struggles of the 1960s and 1970s were merely necessary developments for the continuation of the system,' how can one ever engage in social struggles that are 'genuine negations' and not 'artificial negations'?! The absence of large working class parties in North America (compared to Western Europe) seems to breed a peculiar form of abstracted radical pessimism where faith in the capacity of capitalism is widely shared by both its apologists and its so-called opponents such as Piccone, Luke and Willhelm" Frankel, Boris. 1982. "Identifying Dominant Misconceptions of States." Thesis Eleven 4:97-123.

8. "One's income does not necessarily determine what one thinks, but in the long run experience proves that a mental attitude becomes untenable when it no longer fits in with the way one produces one's means of subsistence. It is never easy to think one way and live another. An intellectual who lives on the right and thinks on the left is in a precarious position and is constantly torn in two. It is not surprising that there are fewer and fewer of them, or that there are more and more men and women who are sincerely convinced that the words 'left' and 'right' are meaningless: it is cheaper to change a way of thought than to repudiate a way of life" Debray, Regis. 1981. Teachers, Writers, Celebrities: The Intellectuals of Modern France. Translated by D. Macey. London: Verso . 


\section{References}

Adorno, Theodor W. 2000. Introduction to Sociology, Edited by C. Godde. Translated by E. Jephcott. Stanford: Stanford University Press.

Agger, Ben. 1990. The Decline of Discourse: Reading, Writing and Resistance in Postmodern Capitalism. New York: The Falmer Press.

-. 2000. Public Sociology: From Social Facts to Literary Acts. Lanham, Md.: Rowman \& Littlefield Publishers.

Bourdieu, Pierre. 1969. "Intellectual Field and Creative Project." Social Science Information 8:89-119.

-. 1993. The Field of Cultural Production: Essays on Art and Literature, Edited by R. Johnson. New York: Columbia University Press.

Breines, Paul. 1988. “Recalling Telos.” Telos 75:36-47.

Debray, Regis. 1981. Teachers, Writers, Celebrities: The Intellectuals of Modern France. Translated by D. Macey. London: Verso

-. 2007. "Socialism: A Life-Cycle." New Left Review July-August:5-28.

Frankel, Boris. 1982. "Identifying Dominant Misconceptions of States.” Thesis Eleven 4:97-123.
Genosko, Gary, Samir Gandesha, and Kristina Marcellus. 2002. "A Crucible of Interdisciplinarity: The Toronto Telos Group." TOPIA 8:1-18.

Jameson, Frederic. 1984. "Postmodernism, or The Cultural Logic of Late Capitalism.” New Left Review 146:53-92.

—. 2009. "Sandblasting Marx." New Left Review 55:134-142.

Lefebvre, Henri. 1991. The Production of Space. Translated by D. Nicholson-Smith. Oxford: Blackwell Publishing.

Leslie, Esther. 2008. “”Telos”.” Pp. 24-25 in Times Literary Supplement, vol. 5509.

Ost, David. 1994. “Search for Balance.” Telos 101:137-154.

Piccone, Paul. 1999. “elements Interview.” Telos 117:133-166.

-. 2008a. "20 Years of Telos." Pp. 231-258 in Confronting the Crisis: Writings of Paul Piccone, edited by G. Ulmen. New York: Telos Press Publishing.

-. 2008b. "From the New Left to the New Populism." Pp. 287-329 in Confronting the Crisis: Writings of Paul Piccone, edited by G. Ulmen. New York: Telos Press Publishing.

Therborn, Goran. 2007. "After Dialectics: Radical Social Theory in a Post-Communist World.” New Left Review 43:63-114. 